\title{
Coordination Appraisement Research of Industrialization and Greenization Based on China's Provincial Data
}

\author{
Liangwen Yue ${ }^{1,2, a}$, Menggang $\mathrm{Li}^{1}$ \\ ${ }^{1}$ China Center for Industrial Security Research, Beijing Jiaotong University, Beijing, China; \\ ${ }^{2}$ Beijing Center for Industrial Security and Development Research, Beijing, China \\ aliangwenylw@163.com.
}

\begin{abstract}
This paper constructed and coordination appraisement method of industrialization and greenization based on the coupling theory in physics; and gave an empirical test and analysis on the support of Chinese provincial regional data for the year 2014. Research results indicates: the coordination appraisement method of industrialization and greenization of this paper constructed is a scientific and comprehensive appraisement method of coincidence the idea of sustainable development. The method has considerable significance theoretical innovation and practical application value, can appraise and analyze availably the interaction and coordination between industrialization and greenization, provide decision references and theory supports for a nation or a region to develop new type industrialization, realize sustainable development.
\end{abstract}

Keywords: industrialization; greenization; coupling coordination degree; sustainable development; green growth.

\section{Introduction}

Greenization is the significative practical way to bring about the drawbacks of the road of industrialization. Greenization is the major support for the sustainable development of human society. But the greenization research has just begun, at home and abroad, and the research of industrialization and greenization interaction and coordination development is very little, so it is difficult to guide the practice. Therefore, it has a significant theoretical and practical significance to research theory and practice of the interaction and coordination of industrialization and greenization, to take on a new road of industrialization and to realize sustainable development for the human society. Based on the above considerations, this paper constructed an interaction and coordination appraisement method of industrialization and greenization based on the coupling theory in physics; and gave an empirical test and analysis on the support of Chinese provincial regional data for the year 2014.

\section{The related research review}

\subsection{The literatures review of related problems}

The related literatures review of Industrialization and Greenization are as follows. Xu etc. [1] studied the synchronous development of industrialization, informatization, urbanization, agricultural modernization. At present, the concept of green growth with the highest citation rate is given by OECD [2]. Campiglio [3] explored green growth in the service industry. Baharat [4] considered the sustainable development of human society depends on the ecological and green transformation of the industry. Dercon [5] researched the role of green growth on climate change and aiding poor countries. McKendry and Janos [6] discussed green growth and sustainable development of industrial cities in developed countries. Feng etc. [7] explored the concept of greenization in china. Liu etc. [8] studied the evolution characteristics of greenization in China. Ding etc. [9] give a general introduction on progress of coordinated development of industrialization, urbanization, agricultural modernization, informationization, and greenization in China, and other literatures, etc.

\subsection{Limitations of existing research}

(1)The research on the industrialization needs to be further deepened at home and abroad.

(2) The research on the greenization is at the initial stage, and the research is not deep enough, and the research has not formed theoretical system. 
(3)The interaction and coordination research of industrialization and greenization is less, and it is difficult to guide the practice.

This paper made up for these shortcomings.

\section{Coordination appraisement method of industrialization and greenization}

\section{1 coordination appraisement indicators system of industrialization and greenization}

This paper constructed a coordination appraisement of industrialization and greenization, Table 1 is the appraisement indicators system. In this paper, we use AHP (Analytic Hierarchy Process) Method to synthesize 4 indicators (Degree of industrialization etc.) into industrialization comprehensive index. Similarly, we use AHP Method to synthesize 4 indicators (Renewable energy power generation ratio etc.) into greenization comprehensive index.

Table 1. Coordination appraisement indicators system of industrialization and greenization

\begin{tabular}{|c|c|c|c|}
\hline & $\begin{array}{l}\text { Industrialization } \\
\text { and greenization }\end{array}$ & Evaluation indicator & Concrete representation \\
\hline \multirow{8}{*}{$\begin{array}{l}\text { Coordination } \\
\text { degree of } \\
\text { industrialization } \\
\text { and greenization }\end{array}$} & \multirow{4}{*}{$\begin{array}{l}\text { Industrialization } \\
\text { comprehensive } \\
\text { index }\end{array}$} & $\begin{array}{c}\text { Degree of } \\
\text { industrialization }\end{array}$ & $\begin{array}{l}\text { Second industry added } \\
\text { value/GDP(proportion) }\end{array}$ \\
\hline & & $\begin{array}{l}\text { Industrial employment } \\
\text { proportion }\end{array}$ & $\begin{array}{c}\text { Second industry employment number/total } \\
\text { number of social workers(proportion) }\end{array}$ \\
\hline & & $\begin{array}{l}\text { Industrial per capita } \\
\text { productivity }\end{array}$ & $\begin{array}{l}\text { Second industry value added/second industry } \\
\text { employment number(proportion) }\end{array}$ \\
\hline & & $\begin{array}{c}\text { Industrial science and } \\
\text { technology level }\end{array}$ & $\begin{array}{c}\text { R\&D funding/second industry added } \\
\text { value(proportion) }\end{array}$ \\
\hline & \multirow{4}{*}{$\begin{array}{l}\text { Greenization } \\
\text { comprehensive } \\
\text { index }\end{array}$} & $\begin{array}{l}\text { Renewable energy } \\
\text { power generation ratio }\end{array}$ & $\begin{array}{c}\text { Renewable energy power generation accounts } \\
\text { for the proportion of total energy power } \\
\text { generation (percentage) }\end{array}$ \\
\hline & & $\begin{array}{c}\text { Per capita sulfur dioxide } \\
\text { emissions }\end{array}$ & $\begin{array}{l}\text { Annual average sulfur dioxide emissions per } \\
\text { capita(ton/person) }\end{array}$ \\
\hline & & $\begin{array}{l}\text { Investment proportion } \\
\text { of environmental } \\
\text { pollution government }\end{array}$ & $\begin{array}{l}\text { Environmental pollution government } \\
\text { investment accounted for GDP (percentage) }\end{array}$ \\
\hline & & GDP energy intensity & $\begin{array}{l}\text { Ten thousand yuan GDP energy } \\
\text { consumption(tons of standard coal) }\end{array}$ \\
\hline
\end{tabular}

3.2 Coupling degree model and coupling coordination degree model

In this paper, the coupling theory of physics subject is introduced, which is used to explore the coordination degree appraisement of industrialization and greenization. The model of coupling theory used in this paper is as follows.

(1) Coupling degree model

Coupling degree model of physics subject is as follows:

$C_{n}=\left\{\frac{\left(U_{1} \times U_{2} \times \ldots \times U_{n}\right)}{\prod\left(U_{i}+U_{j}\right)}\right\}^{1 / n}$

In the above formula, $U_{1}, U_{2}, \cdots, U_{n}$ represent $\mathrm{n}$ systems, $C_{n}$ represent Coupling degrees of the $\mathrm{n}$ systems.

There are two systems(industrialization and greenization) in this paper,So,the coupling degree of the two systems is as follows:

$$
C=C_{2}=\left\{\frac{\left(U_{1} \times U_{2}\right)}{\left(U_{1}+U_{2}\right)^{2}}\right\}^{1 / 2}
$$

In the above formula, $U$ represents industrialization comprehensive index, and $U_{2}$ represents greenization comprehensive index, $C_{2}$ represents coupling degree index $\mathrm{C}$ of the two systems, $0 \leq C<1$.

(2) Coupling coordination degree model

Coupling degree index $\mathrm{C}$ express two system coupling degree, but it can't reflect the actual interaction and coordination degree of the two systems, such as: the industrialization and greenization 
level of a region is low, but we can draw high coupling degree evaluation results, and this is not meaningful. Therefore, we need to introduce coupling coordination index D to measure the degree of interaction and coordination between the two systems.

$$
\begin{aligned}
& D=\sqrt{C \times T} \\
& T=\alpha u_{1}+\beta u_{2}
\end{aligned}
$$

Among them, $\mathrm{D}$ represents coupling coordination index, expresses the degree of interaction and coordination of the systems. T represents comprehensive evaluation index of two systems, reflect the overall efficiency of the two systems. $\alpha$ and $\beta$ represent undetermined coefficients. Generally speaking, we think that industrialization and greenization are equally important. So, $\alpha$ and $\beta$ values are the same, both are 0.5 .

\subsection{Coordination degree appraisement standard of industrialization and greenization}

Coupling coordination index $\mathrm{D}$ is the indicator which measures the degree of interaction and coordination between industrialization and greenization, the measuring standard is in Table 2 .

\begin{tabular}{|c|c|c|c|c|c|}
\hline $\begin{array}{l}\text { Coordination } \\
\text { development } \\
\text { phase }\end{array}$ & $\begin{array}{c}\text { Coupling } \\
\text { coordination } \\
\text { degree of D } \\
\text { value } \\
\end{array}$ & Coordination type & $\begin{array}{l}\text { Coordination } \\
\text { development } \\
\text { phase }\end{array}$ & $\begin{array}{c}\text { Coupling } \\
\text { coordination } \\
\text { degree of } D \text { value }\end{array}$ & $\begin{array}{l}\text { Coordination } \\
\text { type }\end{array}$ \\
\hline \multirow{3}{*}{$\begin{array}{l}\text { Low level } \\
\text { coordination: } \\
\text { Very little } \\
\text { contact }\end{array}$} & $0.0000-0.0999$ & $\begin{array}{l}\text { Extreme lack of } \\
\text { coordination }\end{array}$ & \multirow{3}{*}{$\begin{array}{l}\text { Strengthen } \\
\text { coordination: } \\
\text { Running in } \\
\text { contact }\end{array}$} & 0.5000-0.5999 & $\begin{array}{c}\text { reluctant } \\
\text { coordination }\end{array}$ \\
\hline & $0.1000-0.1999$ & $\begin{array}{l}\text { Serious lack of } \\
\text { coordination }\end{array}$ & & 0.6000-0.6999 & $\begin{array}{c}\text { Primary } \\
\text { coordination }\end{array}$ \\
\hline & $0.2000-0.2999$ & $\begin{array}{l}\text { Moderate lack of } \\
\text { coordination }\end{array}$ & & 0.7000-0.7999 & $\begin{array}{l}\text { Intermediate } \\
\text { coordination }\end{array}$ \\
\hline \multirow{2}{*}{$\begin{array}{c}\text { Start } \\
\text { coordination: } \\
\text { Contend with } \\
\text { each other }\end{array}$} & 0.3000-0.3999 & $\begin{array}{l}\text { Slight lack of } \\
\text { coordination }\end{array}$ & \multirow{2}{*}{$\begin{array}{l}\text { High level } \\
\text { coordination: } \\
\text { Fusion and } \\
\text { symbiosis }\end{array}$} & 0.8000-0.8999 & $\begin{array}{c}\text { Good } \\
\text { coordination }\end{array}$ \\
\hline & $0.4000-0.4999$ & $\begin{array}{l}\text { On the verge of } \\
\text { lack of } \\
\text { coordination }\end{array}$ & & 0.9000-1.0000 & $\begin{array}{l}\text { High quality } \\
\text { coordination }\end{array}$ \\
\hline
\end{tabular}

Table 2. Coordination degree appraisement standard of industrialization and greenization

\section{Appraisement and analysis of the coordination degree of China's industrialization and greenization}

Specific data of each indicator which is showed in table 1,of coordination appraisement between China's industrialization and greenization in 2014,is derived from China Statistical Yearbook (2015), Statistical Yearbook of Chinese various provincial regions in the year 2015, China population and employment statistics yearbook, China industrial economy statistical yearbook, China economic information network statistics database, CNKI"Statistical database of China's economic and social development", People's Republic of China "national statistical database" and other relevant statistical data. According to the coordination appraisement method of industrialization and greenization presented above, we got coordination degree appraisement results of China's industrialization and greenization in 2014, the results are shown in table 3.

The data in table 3 are analyzed as follows. In the coordination degree of China's provincial regional industrialization and greenization in 2014, Shanghai, Tianjin, Beijing belong to the primary coordination. Guangdong, Jiangsu, Zhejiang, Fujian, Shandong, Chongqing belong to reluctant coordination. Liaoning, Shaanxi, Jilin, Hainan, Heilongjiang, Hubei, Henan, Hunan, Hebei, Sichuan, Jiangxi are on the verge of lack of coordination. Anhui, Guangxi, Inner Mongolia, Yunnan, Shanxi, Xinjiang, Guizhou, Qinghai, Gansu belong to the Slight lack of coordination. Ningxia, Tibet belong to Moderate lack of coordination. Overall, there are some certain extent coordinations in China's provincial regional industrialization and greenization in 2014, but the degree and level of coordination is not high. At present, the industrial green development plan (2016-2020) which is implemented in China's national level, is an opportunity for the China's provincial region. Every province should hold this opportunity, vigorously promote the local area of industrialization and 
greenization, and promote the coordination between industrialization and greenization; to make industrialization and greenization become the transformative power which promote the development level of the local economy, society, science and technology, and other aspects. This is a necessary way which is used to narrow the regional gap, to make China as a whole realize modernization.

Table 3. Coordination degree appraisement results of industrialization and greenization of Chinese provincial regions in 2014

\begin{tabular}{|c|c|c|c|c|c|}
\hline $\begin{array}{l}\text { Geographical } \\
\text { district }\end{array}$ & $\begin{array}{l}\text { Provincial } \\
\text { region }\end{array}$ & $\begin{array}{c}\text { Coupling } \\
\text { degree index } \\
\text { C }\end{array}$ & $\begin{array}{c}\text { Comprehensive } \\
\text { evaluation } \\
\text { index T }\end{array}$ & $\begin{array}{l}\text { Coupling } \\
\text { coordination } \\
\text { index D }\end{array}$ & $\begin{array}{l}\text { Coordination degree } \\
\text { appraisement }\end{array}$ \\
\hline North China & $\begin{array}{l}\text { Beijing } \\
\text { Tianjin } \\
\text { Hebei } \\
\text { Shanxi } \\
\text { Inner } \\
\text { Mongolia }\end{array}$ & $\begin{array}{l}0.4931 \\
0.4958 \\
0.3526 \\
0.3390 \\
0.3459\end{array}$ & $\begin{array}{l}0.7426 \\
0.7534 \\
0.5463 \\
0.3475 \\
0.3962\end{array}$ & $\begin{array}{l}0.6051 \\
0.6112 \\
0.4389 \\
0.3432 \\
0.3702\end{array}$ & $\begin{array}{c}\text { Primary coordination } \\
\text { Primary coordination } \\
\text { On the verge of lack of } \\
\text { coordination } \\
\text { Slight lack of coordination } \\
\text { Slight lack of coordination }\end{array}$ \\
\hline $\begin{array}{l}\text { Northeast } \\
\text { China }\end{array}$ & $\begin{array}{l}\text { Heilongjiang } \\
\text { Jilin } \\
\text { Liaoning }\end{array}$ & $\begin{array}{l}0.3867 \\
0.3824 \\
0.3971\end{array}$ & $\begin{array}{l}0.5721 \\
0.5846 \\
0.6183\end{array}$ & $\begin{array}{l}0.4704 \\
0.4728 \\
0.4955\end{array}$ & $\begin{array}{c}\text { On the verge of lack of } \\
\text { coordination } \\
\text { On the verge of lack of } \\
\text { coordination } \\
\text { On the verge of lack of } \\
\text { coordination }\end{array}$ \\
\hline East China & $\begin{array}{l}\text { Shanghai } \\
\text { Jiangsu } \\
\text { Zhejiang } \\
\text { Anhui } \\
\text { Fujian } \\
\text { Shandong } \\
\text { Jiangxi }\end{array}$ & $\begin{array}{l}0.4973 \\
0.4579 \\
0.4625 \\
0.3682 \\
0.4317 \\
0.4264 \\
0.3791\end{array}$ & $\begin{array}{l}0.7692 \\
0.6917 \\
0.6844 \\
0.4038 \\
0.6530 \\
0.6381 \\
0.4357\end{array}$ & $\begin{array}{l}0.6185 \\
0.5628 \\
0.5626 \\
0.3856 \\
0.5309 \\
0.5216 \\
0.4064\end{array}$ & $\begin{array}{l}\text { Primary coordination } \\
\text { reluctant coordination } \\
\text { reluctant coordination } \\
\text { Slight lack of coordination } \\
\text { reluctant coordination } \\
\text { reluctant coordination } \\
\text { On the verge of lack of } \\
\text { coordination } \\
\end{array}$ \\
\hline Central China & $\begin{array}{l}\text { Henan } \\
\text { Hubei } \\
\text { Hunan }\end{array}$ & $\begin{array}{l}0.4029 \\
0.3755 \\
0.3678\end{array}$ & $\begin{array}{l}0.4972 \\
0.5795 \\
0.5328\end{array}$ & $\begin{array}{l}0.4476 \\
0.4665 \\
0.4427\end{array}$ & $\begin{array}{c}\text { On the verge of lack of } \\
\text { coordination } \\
\text { On the verge of lack of } \\
\text { coordination } \\
\text { On the verge of lack of } \\
\text { coordination }\end{array}$ \\
\hline South China & $\begin{array}{l}\text { Guangdong } \\
\text { Guangxi } \\
\text { Hainan }\end{array}$ & $\begin{array}{l}0.4716 \\
0.3597 \\
0.4280\end{array}$ & $\begin{array}{l}0.7213 \\
0.4126 \\
0.5177\end{array}$ & $\begin{array}{l}0.5832 \\
0.3852 \\
0.4707\end{array}$ & $\begin{array}{c}\text { reluctant coordination } \\
\text { Slight lack of coordination } \\
\text { On the verge of lack of } \\
\text { coordination }\end{array}$ \\
\hline $\begin{array}{l}\text { Southwest } \\
\text { China }\end{array}$ & $\begin{array}{l}\text { Chongqing } \\
\text { Sichuan } \\
\text { Guizhou } \\
\text { Yunnan } \\
\text { Tibet }\end{array}$ & $\begin{array}{l}0.4173 \\
0.3694 \\
0.3268 \\
0.3487 \\
0.3126\end{array}$ & $\begin{array}{l}0.6052 \\
0.4539 \\
0.3184 \\
0.3590 \\
0.2618\end{array}$ & $\begin{array}{l}0.5025 \\
0.4095 \\
0.3226 \\
0.3538 \\
0.2861\end{array}$ & $\begin{array}{c}\text { reluctant coordination } \\
\text { On the verge of lack of } \\
\text { coordination } \\
\text { Slight lack of coordination } \\
\text { Slight lack of coordination } \\
\text { Moderate lack of } \\
\text { coordination }\end{array}$ \\
\hline $\begin{array}{l}\text { Northwest } \\
\text { China }\end{array}$ & $\begin{array}{l}\text { Shaanxi } \\
\text { Gansu } \\
\text { Qinghai } \\
\text { Ningxia } \\
\text { Xinjiang }\end{array}$ & $\begin{array}{l}0.3928 \\
0.3357 \\
0.3292 \\
0.3193 \\
0.3425\end{array}$ & $\begin{array}{l}0.5971 \\
0.2849 \\
0.2953 \\
0.2597 \\
0.3365\end{array}$ & $\begin{array}{l}0.4843 \\
0.3093 \\
0.3118 \\
0.2880 \\
0.3395\end{array}$ & $\begin{array}{l}\text { On the verge of lack of } \\
\text { coordination } \\
\text { Slight lack of coordination } \\
\text { Slight lack of coordination } \\
\text { Moderate lack of } \\
\text { coordination } \\
\text { Slight lack of coordination }\end{array}$ \\
\hline
\end{tabular}




\section{Conclusion}

This paper contructed a coordination appraisement method of industrialization and greenization based on the coupling theory in physics; and gave an empirical test and analysis on the support of Chinese provincial regional data for the year 2014. Research results indicates: the coordination appraisement method of industrialization and greenization of this paper contructed is a scientific and comprehensive appraisement method of coincidencing the idea of sustainable development. The method has considerable significance theoretical innovation and practical application value, can appraise and analyz availably the coordination between industrialization and greenization, provide decision references and theory supports for a nation or a region to develop new type industrialization, realize sustainable development.

\section{Acknowledgments}

This study is supported by The National Natural Science Foundation Major International (Regional) Joint Program of China (No.71320107006); The National Social Science Foundation Key Projects of China (No.14AZD090).

\section{References}

[1] Xu Weixiang, Shu Jijun, Tang Gennian. The Measure on the synchronous development of industrialization, informatization, urbanization, agricultural modernization [J]. Economic Geography, 2014, 34(9): 1-6.

[2] OECD. Towards Green Growth [R]. OECD Publishing, 2011: 1-144.

[3] Campiglio Emanuele. The structural shift to green services: A two-sector growth model with public capital and open-access resources [J]. Structural Change and Economic Dynamics, 2014, 30: $148-161$.

[4] Bauhardt Christine. Solutions to the crisis? The Green New Deal, Degrowth, and the Solidarity Economy: Alternatives to the capitalist growth economy from an ecofeminist economics perspective [J].Ecological Economics, 2014, 102:60-68.

[5] Dercon Stefan. Climate change, green growth, and aid allocation to poor countries [J].Oxford Review of Economic Policy, 2014, 30(3): 531-549.

[6] McKendry Corina, Janos Nik. Greening the industrial city: equity, environment, and economic growth in Seattle and Chicago [J]. Int Environ Agreements, 2015, 15: 45-60.

[7] Feng Zhijun, Liu Yanhua, Jin Yong, Guo Qiang, Yan feng. To persist and improve the greenization road of Chinese characteristics [J].China Soft Science, 2015, (9): 1-7.

[8] Liu Kai,Ren Jianlan, Wang Chengxin. The evolution characteristics and influencing factors of China's greenization [J].Urban problems, 2016, 249(4):11-17.

[9] Ding Zhiwei, Zhang Gaisu, Wang Fazeng, Kang Jiayu, Gao Ling. Progress on quantitative evaluation of coordinated development ofindustrialization, urbanization, agricultural modernization, informationization, and greenization in China and reflections $[\mathrm{J}]$. Progress in Geography, 2016, 35 (1): 4-13. 